\title{
Increase in the Capability of Interleukin 2 Gene-Transduced Renal Cell Carcinoma Cells to Induce Cytotoxic Lymphocytes
}

KYOGO ITOH ${ }^{* \dagger \dagger}$, YASUIKI UMEZU* ${ }^{*}$ TATSUO MORITA* ${ }^{*}$, HIDEYUKI SAYA ${ }^{\dagger}$, DAI SEITO*, LAZEL B. AUGUSTUS*, MASANOBU NAKAO ${ }^{\dagger \dagger}$, MOTOKO SAKATA ${ }^{\dagger \dagger}$, JIRO MIYAJIMA ${ }^{\dagger \dagger}$, KAZUHIRO MASUOKA $^{\dagger \dagger}$ AND HIROSHI MATSUI**

Departments of Immunology * and Neuro-oncology ${ }^{\dagger}$, The University of Texas, M. D. Anderson Cancer Center, Houston, TX, USA, ${ }^{* *}$ Ajinomoto Central Research Institute, Kawasaki, 210 and ${ }^{\dagger \dagger}$ Department of Immunology, Kurume University School of Medicine, Kurume, 830 Japan

Received for publication April 15, 1994

\begin{abstract}
Summary: The immunogenicity of human cancer cells transfected with interleukin 2 (IL-2) gene, a potent vaccine candidate, has not yet been fully investigated. Human renal cell carcinoma (RCC) cells transduced with human IL-2 gene (RCC-IL-2) were investigated in vitro for the capability to induce lymphokine-activated killer (LAK) or cytotoxic T lymphocyte (CTL) activity in peripheral blood mononuclear cells (PBMC) or tumor-infiltrating lymphocyte (TIL). The RCC-IL-2 cells stimulated PBMC to demonstrate LAK activity, and also stimulated autologous TILs to proliferate and exhibit cytotoxicity relatively restricted to autologous tumor cells. In contrast, both parental $\mathrm{RCC}$ and RCC transduced with neomycin gene alone failed to induce these activities. These results indicate that RCC-IL-2 cells are more potent than the other RCC cells with regard to inducing cytotoxic lymphocytes against autologous tumor cells.
\end{abstract}

Key words: interleukin 2 gene - renal cell carcinoma - gene transduction - immunogenicity - cytotoxic $\mathrm{T}$ lymphocytes

\section{Introduction}

A large number of studies using animal models provide evidence that tumor cells transfected with cytokine genes are more immunogenic than control tumor cells (Tepper et al. 1989; Ferron et al. 1990; Blankenstein et al. 1991; Mullen et al. 1992). In contrast, few studies have investigated the immunogenicity of human cancer cells transfected with cytokine genes (Gastl et al. 1992; Schendel et al. 1993; Uchiyama et al. 1993). RCC cells are one of the most appropriate tumor cells among various human cancer cells to evaluate immunogenecity; because RCC is partly sensitive to immunotherapy, but resistant to conventional chemo- or radiotherapy (Harris, 1983; Lockburn and DeVere, 1984; Rosenberg et al. 1987).

In this study the capability of RCCIL-2 to induce cytotoxicity in PBMC or

Address correspondence and reprint requests to: Dr. K. Itoh, Department of Immunology, Kurume University School of Medicine, 67 Asahi-machi, Kurume, 830 Japan. 
TILs was investigated. RCC-IL-2 cells stimulated autologous TILs to exhibit cytotoxicity that was relatively restricted to autologous tumor cells.

\section{Materials and Methods}

\section{Tumor cells and gene transduction}

A human RCC cell clone ( $\mathrm{RC} 30$ \#14) from a parental RC30 line (RCC-Pa cells) reported in a previous manuscript (Hayakawa et al. 1992) was used for IL-2 gene transduction. The other tumor cells were RC 7 and RC 100 tumor cell lines, RPM melanoma cells that were resistant to natural killer (NK) activity but susceptible to LAK activity, and K562 NK sensitive tumor cells (Hayakawa et al. 1992). The Xho 1 site or Not 1 site was attached to the 17 th residue or the 532 nd residue of human IL-2 cDNA (Taniguchi et al. 1983), respectively, which was ligated to pBCMGS Neo that had been digested by Xho 1 and Not 1 (Karasuyama et al. 1989). pBCMGS Neo IL-2 or pBCMGS Neo alone was transformed into competent cells (DH5 $\alpha$ ) followed by bacterial growth, colony selection and large-scale plasmid preparation using the CIRCLEPREP KIT (BIO 101, Inc., La Jolla, CA). RC30 \#14 cells growing in petri dishes $(10 \mathrm{~cm}$ diameter) were washed three times with serum-free DMEM followed by the addition of $3 \mathrm{ml}$ of $10 \mu \mathrm{g} / \mathrm{ml}$ lipofectin (BRL, Gaithersberg, MD). The cells were incubated for $60 \mathrm{~min}$ at $37^{\circ} \mathrm{C}$ followed by the addition of $20 \mu \mathrm{g}$ pBCMGS Neo or pBCMGS Neo IL-2. The cells were incubated for $8 \mathrm{hs}$ at $37^{\circ} \mathrm{C}$ followed by the addition of $3 \mathrm{ml}$ DMEM supplemented with $20 \%$ FCS. Three days later, selection by geneticin (GIBCO Lab. Grand Island, New York) began at a concentration of $400 \mathrm{mg} / \mathrm{ml}$ with a gradual increase up to $800 \mathrm{mg} / \mathrm{ml}$. One month later, geneticinresistant tumor cells were tested for their ability to produce IL-2. Only IL-2producing tumor cells were used for cloning at 0.3 cells/well, as reported previously (Hayakawa et al. 1992).

\section{Cytokine assays and RCC-IL-2 cells}

$2 \times 10^{5}$ tumor cells were incubated in $2 \mathrm{ml}$ of culture medium in a 24-well culture plate at $37{ }^{\circ} \mathrm{C}$ for $24 \mathrm{hs}$. The supernatants were collected and cytocentrifuged, and the IL-2 activity in the cellfree supernatant was measured by both a bioassay using an IL-2-dependent NK8 clone as reported previously (Salmeron et al. 1992) and an IL-2 ELISA Kit (Genzyme, Cambridge, MA) (Hayakawa et al. 1991). Recombinant human IL-2 (Shionogi, Japan) (Hayakawa et al. 1992) with a specific activity of $1 \mathrm{pg}=10^{-2}$ units was used as a standard. Five tumor cell clones producing $>10$ units $/ \mathrm{ml}(>1 \mathrm{ng} / \mathrm{ml}$ ) IL-2 per $10^{5}$ cells were established, and one clone RC30 \#14-IL-2 producing clone \#20 (termed RCC-IL-2) was used throughout these studies. An RCC cell clone (RC30 \#14) transduced with the neomycin gene alone was also used as a control (RCC-Neo cells). These supernatants were also tested for their IL-4 and IL-6 activity using the IL-4 ELISA kit (Genzyme) and the IL-6 ELISA kit ( $\mathrm{R} \& \mathrm{D}$ System, Minneapolis, MN), respectively. IL-4 activity was not detectable from any of the cells tested under these culture conditions, while 10 to $20 \mathrm{pg} / \mathrm{ml}$ IL- 6 per $10^{5}$ cells was produced by RCC-Pa, RCC-Neo or RCC-IL-2 cells. 
Reverse transcriptase (RT)-polymerase chain reaction (PCR)

Total RNA was isolated from RCC-Pa or RCC-IL-2 cells using RNA zol ${ }^{\mathrm{TM}} \mathrm{B}$ (Biotecx Lab. Inc., Houston, TX), and a cDNA preparation was performed using the Superscript ${ }^{\mathrm{TM}}$ preamplification system (BRL). The PCR primers used for this study were $\beta$-actin primers (sense primer: 5'CTACAATGAGCTGCGTGTGG, antisense primer: 5'-CGGTGAGGATCTTCATGAGG) (Iijima et al. 1985), IL-2 primers (sense primer: 5'-ATGTACAGGATGCAACTCCTGTCTT, antisense primer: 5'-GTTAGTGTTGAGATGATGCTTTGAC) (Taniguchi et al. 1983), IL-4 primers (sense primer: 5'TCGACACCTATTAATGGGTCTCACC, anti-

$\beta$-action
$\mathrm{IL}-2$
$\mathrm{IL}-4$
$\mathrm{IL}-6$

Fig. 1. Cytokine mRNA expression in RCC-Pa or RCC-IL-2 cells. mRNA was isolated from $1 \times 10^{6}$ cells of RCC-Pa or RCCIL -2 cells. Four-tenths $\mu \mathrm{g}$ of mRNA was provided for the analysis of $\beta$-actin, IL-2, IL-4 or IL-6 expression. sense primer: 5'-ATTAAAATATTCAGCTCGAACACTT) (Yokota et al. 1986) and IL6 primers (sense primer: ATGAACTCCTTCTCCACAAGCGC, antisense primer: GAAGAGCCCTCAGGCTGGACTG) (Hirano et al. 1986). PCR was performed using cDNA (0.4 $\mu \mathrm{g}$ per assay), oligonucleotide primers, dNTPs, Taq DNA polymerase in a DNA thermal cycler (M J Research, Inc., MA) for 35 cycles (denaturation at $94{ }^{\circ} \mathrm{C}$ for $1 \mathrm{~min}$, annealing at $55^{\circ} \mathrm{C}$ for $30 \mathrm{sec}$, and extension at $72{ }^{\circ} \mathrm{C}$ for $30 \mathrm{sec}$ ). RT-PCR amplified mRNA was electrophorezed in a $1.5 \%$ agarose gel and stained with ethidium bromide. RCC-IL-2 cells expressed IL-2, IL-4 and IL-6 at the mRNA level, whereas RCC-Pa cells expressed only IL4 and IL-6 (Fig. 1). RCC-IL-2 cells did not express either interferon (IFN $\gamma$ ) or tumor necrosis factor (TNF $\alpha$ ) at the mRNA level (data not shown).

Lymphocytes and mixed lymphocytetumor cell culture (MLTC)

PBMC from healthy volunteers or TILs from the RC30 patient were prepared as reported previously (Itoh et al. 1988). Briefly, the RCC tumor was minced with scissors followed by treatment with collagenase $(2 \mathrm{mg} / \mathrm{ml})$ and type IV DNase $(0.4$ $\mathrm{mg} / \mathrm{ml}$ ) (Sigma Chemical Co., Mo., USA) for $60 \mathrm{~min}$ at room temperature. Following digestion, the cells were applied on a Ficoll-Hypaque gradient to obtain viable cells. Freshly isolated TILs were cryopreserved at $-130^{\circ} \mathrm{C}$, and thawed on the morning of experiments and were provided for experiments as uncultured TILs. PBMC or TILs were incubated with irradiated (5,000 cGy) RCC-IL-2, parental RC30 \#14 clone (RCC-Pa) or RC30 \#14 clone transduced with pBCMGS Neo alone (RCC-Neo) at an effector to stim- 
ulator ratio of 10:1 in the presence of 0 , 2,20 or $200 \mathrm{U} / \mathrm{ml}$ human recombinant IL-2 kindly provided by Shionogi Res. Lab. (Osaka, Japan) as reported previously (Hayakawa et al. 1992). Stimulation of TILs with tumor cells was repeated every 7 days.

\section{Surface antigen analysis}

TILs were incubated with FITC-conjugated anti-CD3, -CD4 or -CD8mAb (Becton Dickinson, CA, USA) for $30 \mathrm{~min}$ at $4{ }^{\circ} \mathrm{C}$. After washing, the antigenic expression of these cells was analyzed by flow cytometry (EPICS-C, Coulter, FL, USA).

\section{Cytotoxicity and proliferation assays}

A $4-h^{51} \mathrm{Cr}$-release assay was used to measure cytotoxicity (Itoh et al. 1988).
Cytotoxicity was also measured in the presence of $10 \mu \mathrm{g} / \mathrm{ml}$ anti-CD3mAb or normal mouse IgG (Becton Dickinson). Proliferation was measured by the ${ }^{3} \mathrm{H}$ TdR uptake assay and also by the enumeration of the fold increase of lymphocytes as compared to the original number of cells used for the culture (Itoh et al. 1988).

\section{Results and Discussion}

Effect of $X$-ray radiation on $R C C-I L-2$ cells

RCC-IL-2 cells were exposed to Xrays at various doses up to 20,000 cGy and their viability and capability to produce IL-2 were measured 24 hs after the irradiation. Non-irradiated RCC-IL-2 cells

TABLE 1.

Susceptibility of RCC-IL-2 cells to NK or LAK activity ${ }^{a}$

\begin{tabular}{lcccc}
\hline \multirow{2}{*}{ Effector cells } & Incubation & \multicolumn{3}{c}{ Specific Cytotoxicity $\left(\mathrm{LU} / 10^{6}\right) \mathrm{VS}$} \\
\cline { 3 - 5 } & Time (HR) & RCC-Pa & RCC-Neo & RCC-IL-2 \\
\hline PBMC & 4 & $<0.1$ & $<0.1$ & $1.0^{\mathrm{b}}$ \\
PBMC & 12 & 0.1 & 0.1 & $4.5^{\mathrm{b}}$ \\
PBMC & 24 & 1.0 & 0.4 & $10.0^{\mathrm{b}}$ \\
IL-2 activated PBMC & 4 & 67 & 90 & $250^{\mathrm{b}}$ \\
\hline
\end{tabular}

a: PBMC from healthy donors $(n=5)$ were used as NK cell sources. Those activated with $200 \mathrm{U} / \mathrm{ml}$ exogenous IL-2 for 3 days were used as LAK cell sources. Tumor cells were trypsinized, ${ }^{51} \mathrm{Cr}$-labeled, washed and incubated for $18 \mathrm{hs}$ in wells of a 96 -well flat microplate (5,000 cells/well). After washing, effector cells were added to the wells in triplicate at effector to target cell ratios of 40:1, 20:1, and 10:1. Spontaneous release did not exceed $20 \%$ of maximum release by a $4 \mathrm{~h}$ assay or $30 \%$ by $12-$ and 24 -h assays. The values represent means $(n=5)$ of lytic units (LU) per $10^{6}$ effector cells. One LU represents numbers of effector cells to lyse $30 \%$ of $10^{4}$ target cells.

b: $p<0.01$ as compared to the others (Student's two-tailed t-test). 
$\left(1 \times 10^{5}\right.$ cells $)$ produced 20 to $60 \mathrm{U} / \mathrm{ml}(2$ to $6 \mathrm{ng} / \mathrm{ml}$ ) IL-2 in the supernatants. Irradiated RCC-IL-2 cells (3,000 to 10,000 cGy) were generally viable $(>70 \%)$ and they produced 10 to $45 \mathrm{U} / \mathrm{ml}$ IL-2 (1 to $4.5 \mathrm{ng} / \mathrm{ml} / 10^{5}$ cells). These results indicate that RCC-IL-2 cells were relatively resistant to X-ray radiation. Therefore, RCC cells were exposed to $X$ rays at 5,000 cGy when used as stimulator cells in these experiments.

\section{Susceptibility to NK or LAK activity}

Freshly isolated PBMC or IL-2-activated PBMC were used to measure NK or LAK activity, respectively (Table 1). NK activity (LU/10 $10^{6}$ cells) against RCC$\mathrm{Pa}$, RCC-Neo, or RCC-IL-2 cells was respectively $<0.1,<0.1$ or 1 in a $4-\mathrm{h}{ }^{51} \mathrm{Cr}$ release assay, $0.1,0.1$ or 4.5 in a $12-\mathrm{h}$ assay and 1, 0.4 or 10.0 in a 24-h assay (Table 1). LAK activity against RCC-IL-2 cells (250 LU) in a 4-h ${ }^{51} \mathrm{Cr}$-release assay was three to four times higher than that against either RCC-Pa (67 LU) or RCCNeo cells (90 LU) (Table 1). These results indicate that the transduction of the IL-2 gene to human RCC cells increased their susceptibility to NK or LAK activity. The increased susceptibility would be primarily due to IL-2 produced by the RCC-IL-2 because IL-2 is a potent NK or LAK cell activator (Itoh et al. $1985 a, b$ ).

\section{Capability to induce LAK activity}

PBMC from healthy donors were incubated for four days with irradiated $(5,000$ cGy) RCC-IL-2 or other cell types in the presence or absence of exogenous IL-2 $(20 \mathrm{U} / \mathrm{ml})$ followed by measurements of

TABLE 2.

Capability of inducing LAK cells ${ }^{a}$

\begin{tabular}{cccccc}
\hline \multirow{2}{*}{$\begin{array}{c}\text { Donor } \\
(\mathrm{PBMC})\end{array}$} & $\begin{array}{c}\text { Exogenous } \\
\mathrm{IL}-2\end{array}$ & \multicolumn{4}{c}{$\begin{array}{c}\text { Proliferation (cpm, } \times 10-3) \text { and LAK activity } \\
\text { (LU) (in parenthesis) in response to }\end{array}$} \\
\cline { 3 - 6 } & & medium & RCC-Pa & RCC-Neo & RCC-IL-2 \\
\hline \multirow{2}{*}{1} & 0 & $2.9 \pm 0.1(0.2)$ & $10.2 \pm 3.9(0.2)$ & $4.6 \pm 2.3(<0.1)$ & $31.3 \pm 8.7^{\mathrm{b}}(>500)$ \\
& $20 \mathrm{U} / \mathrm{ml}$ & $18.0 \pm 5.4(3.4)$ & $23.7 \pm 6.1(3.4)$ & $9.0 \pm 2.0(2.2)$ & $30.2 \pm 1.2^{\mathrm{b}}(>500)$ \\
2 & 0 & $0.8 \pm 0.3(0.2)$ & $0.3 \pm 0.6(0.2)$ & $3.2 \pm 1.4(<0.1)$ & $33.9 \pm 5.1^{\mathrm{b}}(>500)$ \\
& $20 \mathrm{U} / \mathrm{ml}$ & $9.2 \pm 2.3(8.3)$ & $33.2 \pm 9.2(8.3)$ & $11.7 \pm 8.4(7.4)$ & $34.5 \pm 7.6^{\mathrm{b}}(>500)$ \\
\hline
\end{tabular}

a: PBMC from healthy donors were incubated for 4 days with medium alone, irradiated (5,000 cGy) RCC-Pa, RCC-Neo or RCC-IL-2 cells at an effector to stimulator ratio of 10: 1 in the presence or absence of $20 \mathrm{U} / \mathrm{ml}$ exogenous IL-2 in the culture. Experiments were performed in six different individuals with consistent results. Two cases are shown in the table. ${ }^{3} \mathrm{H}-\mathrm{TdR}(0.5 \mu \mathrm{Ci} /$ well $)$ was added to wells $\left(10^{5} \mathrm{PBMC} / 0.2 \mathrm{ml} /\right.$ well $)$ of 96 -well flat bottom microplates, 6 hs before harvesting. Proliferation of irradiated tumor cells $\left(10^{4}\right.$ cells/ well) alone was $<500 \mathrm{cpm}$. The values represent mean $\pm \mathrm{SD}$ of $\mathrm{cpm}$ from triplicate determinations. To measure cytotoxicity, PBMC were harvested from wells $\left(2 \times 10^{6} \mathrm{PBMC} /\right.$ well $)$ of 24 -well culture plates, washed and tested for cytotoxicity against RPM melanoma cells. LAK activity represents $\mathrm{LU} / 10^{6}$ effector cells.

b: Significantly higher $(\mathrm{p}<0.05)$ than the others (Student's two-tailed t-test). 
their proliferation and LAK activity against RPM melanoma cells (Table 2). RCC-IL-2 cells induced both the highest proliferative response and the highest LAK activity in the absence of exogenous IL-2. Addition of $20 \mathrm{U} / \mathrm{ml}$ (Table 2) or 200 U/ml (data not shown) exogenous IL-2 failed to augment these responses. These results indicate that RCC-IL-2 cells by themselves were sufficient for LAK cell induction and could substitute for exogenous IL-2 under these short term culture conditions. These results could also be partially explained by the capability of RCC-IL-2 cells to produce IL-2, which in turn could induce LAK activity in PBMC (Itoh et al. $1985 a, b$ ).

PBMC from healthy donors were stimulated with irradiated (5,000 cGy) RCC$\mathrm{Pa}$ or RCC-IL-2 every 7 days for up to 5 weeks in the presence of $0,2,20$ or 200 $\mathrm{U} / \mathrm{ml}$ exogenous IL-2. The PBMC increased in number for up to 3 weeks in a culture with exogenous IL-2 alone or IL-2 plus RCC-Pa cells, but not with RCC-IL-2 cells even in the presence of exogenous IL-2 (Table 3). Cytotoxicity was tested only once at 3 days after the second stimulation (Table 3). The PBMC that were stimulated with RCC-Pa demonstrated higher cytotoxicity to RC30 cells and lower cytotoxicity to either RC7 or melanoma tumor cells (RPM). The PBMC cultured with IL-2 alone failed to lyse RC30 or RC7 cells, but demonstrated lower levels of lysis to RPM. Cytotoxicity in PBMC that were stimulated with RCCIL-2 was not tested because of the limited numbers of the effector cells. These results indicate that RCC-IL-2 cells markedly inhibited the IL-2-dependent proliferation of PBMC during prolonged incubation periods.
Autologous PBMC for RCC-IL-2 cells were not available because the patient died of cancer several months after surgery. Allogeneic PBMC whose HLA-A locus was matched to an RC30 patient were also very difficult to obtain because of a unique HLA-A type (A-30 and Aw 34). Therefore, PBMC from six different healthy donors were used as effectors in these studies. In all individuals, the PBMC that were stimulated with RCC-IL-2 demonstrated significant DNA synthesis in a 4 day assay in association with LAK activity (Table 2). These PBMC, however, did not increase in number under all the culture conditions employed here, which included i) incubation with IL-2 alone (data not shown); ii) restimulation with RCC-IL-2 with or without various doses of exogenous IL-2 in the culture (Table $3)$; iii) restimulation with $\mathrm{RCC}-\mathrm{Pa}$ or RCC-Neo with or without exogenous IL2 (data not shown). RCC-Pa (Table 3) as well as RCC-Neo (data not shown) induced proliferation of allogeneic PBMC with a cytotoxicity that was relatively restricted to $\mathrm{RC} 30$ cells, suggesting that RC30 cells possessed the capability to induce allospecific CTLs by a standard MLTC. Either transduction of a pBCMGS Neo gene into RCC-Pa or the following selection with G418 might not be involved in this failure because RCC-Neo induced the proliferation of PBMC. The failure of RCC-IL-2 cells to induce the actual increase in number of PBMC might be largely due to the unresponsiveness to IL-2 in PBMC after the initial contact with RCC-IL-2. It will be important to test whether this is the case for autologous PBMC and to investigate the mechanisms involved in this failure. 
TABLE 3.

Inability of RCC-IL-2 cells to induce proliferation of PBMC ${ }^{a}$

\begin{tabular}{|c|c|c|c|c|c|c|c|c|}
\hline \multirow{2}{*}{ Stimulators } & \multirow{2}{*}{$\begin{array}{l}\text { Exo. } \\
\text { IL-2 } \\
(\mathrm{U} / \mathrm{ml})\end{array}$} & \multicolumn{4}{|c|}{ Proliferation $\left(\times 10^{6}\right.$ cells $)$} & \multicolumn{3}{|c|}{ Cytotoxicity (LU/106 cells) } \\
\hline & & 1 & 2 & 3 & 5 (wks) & $\mathrm{RC}-30$ & $\mathrm{RC}-7$ & RPM \\
\hline \multirow[t]{4}{*}{ None } & 0 & 0.5 & 0.9 & 0.2 & $<0.1$ & $-(\mathrm{ND})^{\mathrm{b}}$ & - & - \\
\hline & 2 & 0.5 & 0.9 & 0.2 & $<0.1$ & - & - & - \\
\hline & 20 & 0.7 & 2.6 & 0.5 & $<0.1$ & 0.1 & 0.1 & 1.7 \\
\hline & 200 & 0.8 & 10.1 & 10.5 & 1.8 & 0.5 & 0.5 & 2.5 \\
\hline \multirow[t]{4}{*}{ RCC-Pa } & 0 & 0.5 & 1.3 & 0.3 & $<0.1$ & - & - & - \\
\hline & 2 & 0.8 & 1.5 & 0.4 & $<0.1$ & - & - & - \\
\hline & 20 & 1.1 & 1.7 & 0.6 & $<0.1$ & 33.3 & 0.5 & 5.6 \\
\hline & 200 & 1.4 & 16.8 & 14.0 & 6.0 & 42.7 & 1.0 & 10.5 \\
\hline \multirow[t]{4}{*}{ RCC-IL-2 } & 0 & 0.4 & 0.5 & 0.5 & $<0.1$ & - & - & - \\
\hline & 2 & 0.4 & 1.0 & 0.4 & $<0.1$ & - & - & - \\
\hline & 20 & 0.4 & 0.3 & 0.5 & $<0.1$ & - & - & - \\
\hline & 200 & 0.5 & 0.7 & 0.7 & $<0.1$ & - & - & - \\
\hline
\end{tabular}

a: PBMC from six healthy donors were incubated with medium alone, irradiated $(5,000 \mathrm{rad}) \mathrm{RCC}-\mathrm{Pa}, \mathrm{RCC}-\mathrm{Neo}$ or RCC-IL-2 cells at an effector $\left(1 \times 10^{6} \mathrm{PBMC} / \mathrm{well}\right)$ to stimulator cell ratio $\left(1 \times 10^{5}\right.$ tumor cells/well) of $10: 1$ in wells of 24 well culture plates in the presence of $0,2,20$ or $200 \mathrm{U} / \mathrm{ml}$ exogenous IL-2 in the culture. PBMC were harvested, washed and stimulated with the same stimulators every 7 days for up to 42 days at an effector to stimulator cell ratio of 10:1. Experiments were performed in six different donors with consistent results and one representative group of data is shown in this table. Results with RCC-Pa cells were almost the same as those with RCC-Neo cells (data not shown).

b. ND: not determined.

Capability to induce CTL activity in TILs

Uncultured TILs from the RC30 patient were stimulated with irradiated (5,000 cGy) RCC-IL-2, RCC-Pa or RCCNeo cells every 7 days for up to 4 weeks in the presence of 0,2 or $20 \mathrm{U} / \mathrm{ml}$ exogenous IL-2 in the culture. Their proliferation and cytotoxicity against five different tumor cells, the autologous RC30 tumor cell line (RC30-14), allogeneic RC7 and $\mathrm{RC} 100$ tumor cell lines, the melanoma cell line (RPM), and K562 tumor cells, were measured (Fig. 2).
TILs increased in number by 3.5 times 1 week after the stimulation with RCCIL-2 cells regardless of the presence or absence of exogenous IL-2 in the culture (Fig. 2a). Exogenous IL-2 facilitated the proliferation of TILs at 2 weeks in the culture. In contrast, TILs failed to proliferate with any of the other culture conditions (data not shown). TILs stimulated by RCC-IL-2 cells in the presence of 2 $\mathrm{U} / \mathrm{ml}$ exogenous IL-2 were tested for surface phenotypes and their cytotoxicity was measured 3 days after the third 

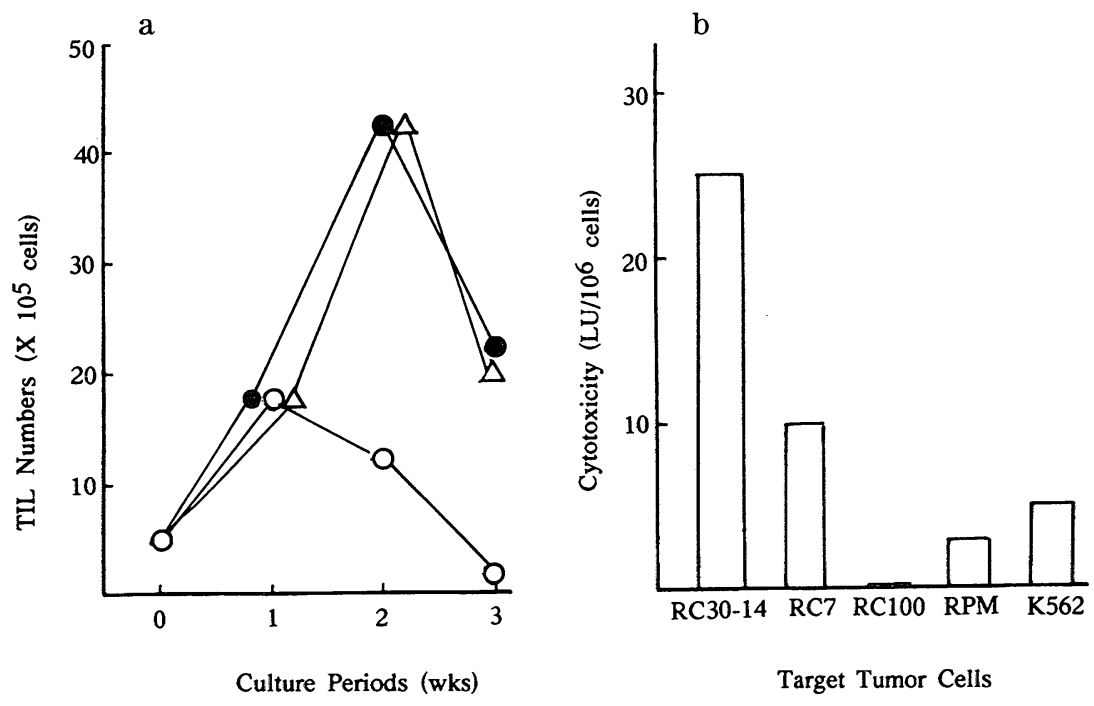

Fig. 2. Capability of inducing CTL activity. Uncultured TILs $\left(5 \times 10^{5}\right.$ $\mathrm{TIL} / 2 \mathrm{ml} /$ well) were incubated with medium alone, irradiated (5,000 cGy) RCC-IL-2, RCC-Pa or RCC-Neo cells in the presence of $0,2,20 \mathrm{U} / \mathrm{ml}$ exogenous IL-2 for up to 4 wks. Stimulation with irradiated tumor cells was repeated every 7 days. a: TIL proliferation in culture with RCC-IL-2 cells was measured by the enumeration of viable numbers of TILs in the absence (-O-) or presence of $2 \mathrm{U} / \mathrm{ml}(-\bullet-)$ or $20 \mathrm{U} / \mathrm{ml}\left(-\triangle_{-}\right)$of exogenous IL-2. TIL did not proliferate with the other culture conditions and those results are not shown. b: TIL stimulated by RCC-IL-2 cells in the presence of $2 \mathrm{U} / \mathrm{ml}$ exogenous IL-2 was tested for cytotoxicity at day 17 of the culture against five different tumor cells by a 4 - $h{ }^{51} \mathrm{Cr}$-release assay at three different effector to target cell ratios. The values represent LU $/ 10^{6}$ effector cells.

stimulation (17 days after the initiation of the culture). These activated TILs consisted of $98 \% \mathrm{CD}^{+}, 42 \% \mathrm{CD}^{+}$and $51 \%$ $\mathrm{CD}^{+} \mathrm{T}$ cells, and had the highest cytotoxicity to autologous RC30 tumor cells (HLA-A30, Aw34, B5<w4>, Bw57, Cw7, Cw8, DR2, DQw1), modest levels of lysis against allogeneic RC7 tumor cells (HLA$\mathrm{A} 2,-\mathrm{A} 3, \mathrm{~B} 35<\mathrm{w} 6>, \mathrm{B} 44<\mathrm{w} 4>, \mathrm{C} 4, \mathrm{DR} 8$, DRw13, DQw1, DQw4), no cytotoxicity to allogeneic RC100 tumor cells (HLA-A1, A-25, B6, Bw50, Cw4, DR8), a low level of lysis to RPM melanoma tumor cells or
K562 tumor cells (Fig. 2b). Addition of anti-CD3mAb, but not normal mouse IgG, to the cytotoxicity assay abrogated the cytotoxicity to autologous tumor cells (data not shown). TILs stimulated by RCC-IL-2 cells in the presence of $20 \mathrm{U} / \mathrm{ml}$ exogenous IL-2 demonstrated a similar pattern of cytotoxicity (35 LU vs RC3014, $8 \mathrm{LU}$ vs RC7, <0.1 LU vs RC100, $3 \mathrm{LU}$ vs RPM and $6 \mathrm{LU}$ vs K562). Thus RCC-IL2 cells possessed the capability to induce CTL activity in TILs relatively specific to autologous tumor cells in the presence 
of exogenous IL-2. HLA restriction involved in this cytotoxicity was not clear from this limited information partly because of the unique HLA-A antigens (A30 and Aw34) in the RC30 patient.

RCC-TILs usually proliferated well in culture with exogenous IL-2 alone, and displayed MHC-nonrestricted cytotoxicity (Belldegrun et al. 1988; Finke et al. 1990; Kim et al. 1990). IL-2 alone or IL-2 plus RCC-Pa or RCC-Neo cells failed to induce TIL proliferation in these studies. Low doses (2 and $20 \mathrm{U} / \mathrm{ml}$ ) of exogenous IL-2 were used in these studies, and could be at least partly responsible for the failure, because higher doses $(>200 \mathrm{U} / \mathrm{ml})$ of exogenous IL-2 induced proliferation of TILs from the RC30 patient and these IL2-activated TILs demonstrated MHCnonrestricted cytotoxicity (data not shown). Frozen samples instead of freshly isolated TILs were used for the study, and could also be in part responsible for the failure, because IL-2-induced proliferation of TILs using frozen samples was more difficult to obtain than with fresh samples.

Both IL- 4 and IL-6 expressed by RCCIL-2 cells at mRNA levels (Fig. 1) would not be primarily involved in the capability of RCC-IL-2 cells to induce CTL activity since RCC-Pa cells as well as RCC-Neo cells (data not shown) also expressed both IL- 4 and IL- 6 at mRNA levels. More than half of RCCs expressed IL-6 gene, as judged by Northern blot analysis (Takenaka et al. 1991), and the serum level of IL- 6 was detectable in 48 of 138 patients with metastatic RCC (Blay et al. 1992). RC30-14 clones also produced detectable levels of IL- 6 , regardless of IL-2 gene transduction. IL-4 expression at the mRNA level in RCC clones has not been reported in the literature. The biological roles of IL- 4 and/or IL- 6 in the immunogenicity of human RCCs need to be fully investigated.

In summary, these results indicate that human RCC cells transduced with an IL-2 gene could be more potent to induce cytotoxic lymphocytes only in TILs.

Acknowledgments: The authors would like to thank Dr. H. Karasuyama (Tokyo Univ., Japan) for providing the pBCMGS Neo vector, and Mrs. T. Iwamaru for preparation of the manuscript. This work was supported in part by a Grant-in-Aid of the Comprehensive 10-year Strategy for Cancer Control from the Ministry of Health and Welfare and the Ishibashi Research Fund, Japan.

\section{References}

Beldoegrun, A., Muul, L.M. and Rosenberg, S.A. (1988). Interleukin 2 expanded tumorinfiltrating lymphocytes in human renal cell carcinoma: isolation, characterization, and antitumor activity. Cancer Res. 47, 206-214.

Blankenstein, T., Qin, Z., Uberla, K., Muller, W., Rosen, H. et al. (1991). Tumor suppression after tumor cell-targeted tumor necrosis factor $\alpha$ gene transfer. J. Exp. Med. 173, 1047-1052.

Blay, J.-Y., Negrier, S., Combaret, V., Attali, S., Golllot, B. et al. (1992). Serum level of interleukin 6 as a prognosis factor in metastatic renal cell carcinoma. Cancer Res. 52, 3317-3322.

Fearon, E.R., Pardoll, D.M., Itaya, T., Golumbek, P., Levitsky, H.I. et al. (1990). Interleukin-2 production by tumor cells bypasses $\mathrm{T}$ helper function in the generation of an antitumor response. Cell 60, 397-403.

Finke, J.H., Raynan, P., Alexander, J., Edinger, M., 
TubBs, R.R. et al. (1990). Characterization of the cytotoxic activity of $\mathrm{CD}^{+}$and $\mathrm{CD}^{+}$ tumor-infiltrating lymphocytes in human renal cell carcinoma. Cancer Res. 50, 23632370.

Gastl, G., Finstad, C.L., Guarini, A., Bosl, G., GiLOA, E. et al. (1992). Retroviral rectormediated lymphokine gene transfer into human renal cell cancer cells. Cancer Res. 52, 6229-6236.

HARRIS, O.T. (1983). Hormonal therapy and chemotherapy of renal cell carcinoma. Semin. Oncol. 10, 422-430.

Hayakawa, K., Morita, T., Augustus, L.B., van EschenBach, A.C. and IтоH, K. (1992). Human renal cell carcinoma cells are able to activate natural killer cells. Int. J. Cancer 51, 290-295.

Hayakawa, K., Salmeron, M.A., Kohnbluth, J., Bucana, C. and Iтон, K. (1991). The role of IL-4 in proliferation and differentiation of human natural killer cells. Study of an IL-4dependent versus an IL-2-dependent natural killer cell clone. J. Immunol. 146, 24532460.

Hirano, T., Yasukawa, K., Harada, H., Taga, T., Watanabe, Y. et al. (1986). Complementary DNA for a novel human interleukin (BSF-2) that induces $\mathrm{B}$ lymphocytes to induce immunoglobulin. Nature 324, 73-76.

Iljima, N.S., Hamada, H., Reddy, P. and Kakunaga, T. (1985). Molecular structure of the human cytoplasmic $\beta$-actin gene: Interspecies homology of sequences in the introns. Proc. Natl. Acad. Sci. USA 82, 6133-6137.

Itoh, K., Plasoucas, C.D. and Balch, C.M. (1988). Autologous tumor-specific cytotoxic T lymphocytes in the infiltrate of human metastatic melanoma: activation by interleukin 2 and autologous tumor cells, and involvement of the T cell receptor. J. Exp. Med. 168, 1419-1441.

Iтон, K., Shïв, K., Shimizu, Y., Suzuki, R. and KumagAI, K. (1985a). Generation of activated killer (AK) cells by recombinant interleukin 2 (rIL2) in collaboration with interferon $\gamma$ (IFN $\gamma$ ). J. Immunol. 134, 3124-3129.
Itoh, K., Tilden, A., Kumagai, K. and Balch, C.M. $(1985 b)$. Leu $11^{+}$lymphocytes with natural killer (NK) activity are precursors of recombinant interleukin 2 (rIL2)-induced activated killer (AK) cells. J. Immunol. 34, 802-807.

Karasuyama, H., Tohyama, N. and Tada, T. (1989). Autocrine growth and tumorigenicity of interleukin 2-dependent helper $\mathrm{T}$ cells transfected with IL2 gene. J. Exp. Med. 169, 13-25.

Kim, T.Y., von Eschenbach, A.C., Filaccio, M.D., Hayakawa, K., Parkinson, D.R. et al. (1990). Clonal analysis of lymphocytes from tumor, peripheral blood, and nontumorous kidney in primary renal cell carcinoma. Cancer Res. 50, 5263-5268.

Lockburn, A.G. and DeVere, W.R. (1984). Chemotherapy of advanced renal adenocarcinoma. World J. Urol. 2, 136-141.

Mullen, C.A., Coalle, M.M., Levy, A.T., StetlerStevenson, W.G., Liotta, L.A. et al. (1992). Fibrosarcoma cells transduced with the IL6 gene exhibit reduced tumorigenicity, increased immunogenicity, and decreased metastatic potential. Cancer Res. 52, 60206024.

Rosenberg, S.A., Lotze, M.T., MuUl, L.M., Leitman, S., Chang, A.E. et al. (1987). A progress report on the treatment of 157 patients with advanced cancer using lymphokine-activated killer cells and interleukin 2 or high-dose interleukin alone. $\mathrm{N}$. Engl. J. Med. 316, 889-897.

Salmeron, M.A., Morita, T., Hideyuki, S., Plstsoucas, C.D. and Iтон, K. (1992). Lymphokine production by human melanoma tumor-infiltrating lymphocytes. Cancer Immunol. Immunother. 35, 211-217.

Schendel, D.J., Gansbacher, B., Oberneder, R., Kriegmair, M., Hofstetter, A. et al. (1993). Tumor-specific lysis of human renal cell carcinoma by tumor-infiltrating lymphocytes I. HLA-A2 restricted recognition of autologous and allogeneic tumor cells. J. Immunol. 151, 4209-4220.

Takenaka, J., Kaneko, Y., Fukumoto, M., Fukatsu, 
A., Hirano, T. et al. (1991). Enhanced expression of interleukin-6 in primary. human renal cell carcinomas. JNCI 83, 1668-1673.

Taniguchi, T., Matsui, H., Fujta, T., TакаOKa, C., Kashima, N. et al. (1983). Structure and expression of a cloned cDNA for human interleukin-2. Nature 302, 305-310.

Tepper, R.I., Pattengle, P.K. and Leder, P. (1989). Murine interleukin-4 displays potent anti-tumor activity in vivo. Cell 57, 503512.
Uchiyama, A., Honn, D.S.B., Morisaki, T., Kaneda, Y., Yuzuki, D.H. et al. (1993). Transfection of interleukin 2 gene into human melanoma cells augments cellular immune response. Cancer Res. 53, 949-952.

Yokota, T., Otsuka, T., Mosmann, T., Banchereau, J., DeFrance, T. et al. (1986). Isolation and characterization of a human interleukin cDNA clone, homologous to mouse B-cell stimulating factor 1 , that expresses B-cell and $\mathrm{T}$ cell stimulating activities. Proc. Natl. Acad. Sci. USA 83, 5894-5898. 